\title{
Investigating Constraints and Strategies Faced by the Non-English Students in Answering Reading Comprehension TOEFL Test
}

\author{
Nurul Hakimah Hafid ${ }^{1}$, Pupung Purnawarman ${ }^{2}$, Didi Sukyadi \\ \{nurulhakimahkim@upi.edu ${ }^{1}$, purnawarman@upi.edu ${ }^{2}$, dsukyadi@upi.edu ${ }^{3}$ \}
}

Faculty of Language and Literature Education, Indonesian Education University, Indonesia.

\begin{abstract}
Test of English as a Foreign Language (TOEFL) is widely used as a measurement for standardized foreign language students. One of the sections in TOEFL assessed as the part considered by the students is reading comprehension Non-English students surely have the power to accomplish TOEFL test, especially the reading section, even though there may be some struggle or constraints they face. Descriptive qualitative research design was implemented in this study in order to investigate the constraints and strategies in accomplishing reading comprehension on the TOEFL test. The totals of participants were 18 students who have passed the ITP TOEFL test. The results indicate there are three most aspects regarding to the students' struggles of answering the question of reading comprehension, those are vocabulary limitations, hard to find the specific information on the passage, and troubled to identify some features, such as tone, objectives, or course in the passage. Aside from this, any strategies definitely composed to adjust those constraints. Further explanations would be elaborated in this paper. The results of this study would be impeccable to give any suggestions for the students or teachers to upgrade their understanding of the TOEFL test on reading comprehension.
\end{abstract}

Keywords: Constraints, ITP TOEFL, non-English students, reading comprehension, strategies.

\section{Introduction}

In the Education system, reading comprehension is one of the learning parts to get more information from text related to the subject matter. As supported by Grabe, reading in an academic context as a part of learning that requires the students to have the ability in reading and construing the text based on the task in order to achieve the learning outcomes arranged by the teachers [1]. It indicates that the students are required to consider with their competence to incorporate, assess, and be selective carry out the information from the text they read. To measure the students; ability in reading comprehension, the teachers assess it by a test. Since having a proficient ability in English is crucial, therefore, TOEFL is widely used as a measurement or a test for a standardized foreign language students' capability. By the same taken, TOEFL is also used as the main requirement for having a decent job. Aside from those reasons, the domestic universities mostly employ this standardized to be used as a condition for determining whether or not the student can graduate. Similarly, TOEFL is required as a test to ensure the students' competence or skill who thoroughly learn English as a second language [2].

Specifically, the ITP TOEFL test has three sections, which are different from the iBT TOEFL test; those are listening skill, structure and written expression, and reading comprehension test. The score of the last section on the TOEFL test would exceptionally affect 
the determinant test score. Briefly, having intelligence on reading comprehension is necessary to achieve a satisfactory score [3]. Conversely, reading comprehension assessed as one of the students' difficulties especially in the TOEFL test. As stated by Anjomshoa \& Zamanian, among the three tested sections, reading comprehension defined as the foremost aspects on TOEFL test [4]. The students in which the unfamiliar words are commonly there could face this reading section as the obstruction. By the taken, the length and tedious passages are written mostly induced the constraints. Phakiti states that there are some examples of implementing strategies in reading; focus on main idea, skimming, scanning, and guessing [5].

Generally, the TOEFL final score frequently put as a provision in term of academic necessity to measure the students' English skills. It takes an example of the students to intend to continue their Education whether in abroad or not, the university will absolutely ask for their TOEFL certificate or provide own requirement of students' score submission as the requirement for the students' English proficiency. Nevertheless, it is currently utilized as the requirements for the graduation examination and applying for occupation or work at some particular institution. Since this kind of proficiency English test has several advantages for among the scholars, therefore, especially non-English students, they mainly have more power to accomplish the TOEFL test. Even though, in learning English, there some struggles and constraints may they face. In sequence, it is imperative to comprehend what kind of difficulty they faced, in terms of the reading comprehension section in the test, then how to deal with those difficulties.

Furthermore, based on the statements of the problem above, this study tried to investigate the constraints and strategies arraigned by the non-English students on reading section in ITP TOEFL test, then specifically focus on the non-English students who have passed ITP TOEFL in which it is more generally applied in the Indonesian context.

\section{Literature Review}

\subsection{Headings, tables and figures}

The Test of English as a Foreign Language (TOEFL) is the most needed English language test in the world by the reason of it recognized by more than 10.000 colleges, universities, and agencies for about 130 countries. Then, TOEFL scores are accepted by more than 7.500 colleges, universities, and licensing agencies in over 130 countries which requires it as the evaluation of the learners' English proficiency (ETS,2009). TOEFL is an English language test that is highly and internationally acclaimed and recognized [6]. By the same taken, Kurasi has an opinion that TOEFL is the test for evaluating an individual's ability to understand and practice English [7]. It is one of the most important factors to determine whether international students are successful in academic performance or not. Currently, the TOEFL test is required on many occasions; it takes an example of the students who eager to continue their study abroad surely have to own the TOEFL certificate. Similarly, it also needs for the alumnus to find a job either in their country or abroad.

Abboud and Husein concluded that the TOEFL test is defined in two kinds. Firstly, International Testing Program consists of (TOEFL CBT (computer-based), and TOEFL PBT (paper-based). The seconds is Institutional Testing Program is composed into Pre-TOEFL (paper-based) and TOEFL ITP (paper-based) [8]. This study focuses on ITP TOEFL in which three skills are tested; listening, structure, and reading where 677 is the highest, and 217 is the lowest score. Listening part consists of three parts; short dialogues, long conversations, and talks 
involving 50 questions. Next, the structure section consists of 40 questions divided into the structure and writing expression. Then, reading as the last section consists of five passages and 50 questions [9].

\subsection{Reading Comprehension on TOEFL}

Reading categorically claimed as the interaction both the reader and passage [10]. In term of education system, especially English teaching, reading is the foremost skill since it provides students' understanding of gaining the information [11]. Construction in this term means that the students understand the passage when they can grasp the information from the text [12]. Therefore, reading comprehension is the learners' knowledge on the written text and the whole content or aspect accomplished in the passage [13],[14].

Nuttal classified five aspects of reading comprehension which are better to comprehend; finding the main idea, understanding the reference, determining inference, detailed information, and having much vocabulary [15]. In detail, Phillips also categorized those five aspects into 13 skills. The first is finding the main idea assesses on how to locate and recognize it correctly. Secondly, answer the questions investigating the ability to recognize the detailed information, unstated statement, and pronoun reconciliation. Next, the capability to respond to the implicit and transition questions. Fourthly, regarding to the vocabulary knowledge, it also emphasizes on four skills (structural clues meanings, word parts, and identifying the difficult sense based on the context). The last skill is the potential to determine the specific information from the text including tone, objective, and course as well [9].

\subsection{Constraints on Reading TOEFL Test}

Difficulty, constraint, or struggle is any condition when the students are complicated to understand the passage and answer the question in reading the TOEFL test. According to any result of experts' study, most of the students compose any struggle in reading comprehension caused by any reasons, limitation of understanding the whole text is one of the factors [14]. Limited vocabulary and some phrases can prevent the learners to understand the whole text [12]. Similarly, Oktarina of his study found that locating the main idea, implicit and unmentioned answer, and vocabulary matters are belonging to constraints in TOEFL assessed by the sixthsemester English students [3]. In another study, Chawwang found three frequently difficulties found; read any unfamiliar words, cannot identify the topic and vocabulary limitedness [16]. However, Mahmud who involved the sample from non-English students conducted the struggle faced by the students caused by any problems, such as reported by in this research [17]. The result shows several incomprehensions as inadequate English basic ability, lack of English training, and different conditions including age and social status.

\subsection{Strategies in Answering Reading TOEFL Test}

Aside from the previous part, to cope with those constraints, the strategies should be implemented, such as summarizing, generating the questions well, applying skimming and scanning methods [9]. The use of strategy and efficacy obviously influenced by the sutdents' proficiency level of reading. Carrell and Grabe underlined the importance of vocabulary knowledge in reading the English text and noted the non-native students' ability in guessing the words, notably when the texts are too complicated [18]. Consequently, Skehan has noticed that the text could be the big obstacle for the non-native readers, it obviously seen that the passage commonly too long and the questions may be hard to understand [19]. The non-English students 
are surely able to implement those strategies to answer the questions in the reading TOEFL test. Samad et al. concluded that reading strategies are considered as the crucial component to fully understand the whole text and resolve the obstacles face [20].

\section{Methods}

\subsection{Research Design}

This research was conducted based on a descriptive qualitative method with two central points on the constraints and strategies encountered by the non-English students answering reading comprehension in the TOEFL test. This research was categorized as descriptive since it analyzed the phenomenon or the perception towards reading skill on TOEFL, consequently, the result would be described or showed descriptively. Correspondently, Kirk and Miller [21].

Qualitative research design claimed as the socially tradition on social where it crucially depends on the human activity between their circumstances and terminology term. Since this research investigates the students' perception, it can be categorized as qualitative referring to people's observation. Then, the object that was assessed or analyzed can be observed with the senses, Furthermore, to collecting the data, the questionnaire was distributed through the internet by Google form as media for the participants to respond all of the questions. The respondents were treated with enough time for filling out the questionnaire. Next, the data gathered from the questionnaire would be descriptively analyzed and revealed in the table, then following by a clear explanation.

\subsection{Participants}

This study was involving 18 non-English students selected from various universities in Indonesia who have been done the TOEFL test and own the qualified certificate. The participants were selective purposively in which the researcher has the requirement to enfold them as the participants. Purposive sampling is a non-probability sampling method in which the researchers chose sampling units based on his assessment or judgment of what the unit will facilitate investigation [22]. The distinctive characteristic for choosing the respondents was the learners who have passed the TOEFL test in an appropriate score. The specification of the TOEFL level score proposed by Carson et al. [23];

Table 1. TOEFL Classification Level

\begin{tabular}{clc}
\multicolumn{3}{c}{ Table 1. TOEFL Classification Level } \\
\hline No & \multicolumn{1}{c}{ Classification Level } & Score \\
\hline 1 & Elementary & $310-420$ \\
2 & Lower Secondary & $421-480$ \\
3 & Secondary (High Intermediate) & $481-520$ \\
4 & Advanced & $521-677$ \\
\hline
\end{tabular}

Then, the researcher chose the students who are in the range score of high intermediate since it is more suitable than other levels in which they supposed to possess good ability in English.

\subsection{Instrument}

The instrument is the foremost part of the research used to collect the data. In this study, a questionnaire that had been developed by the researcher was used as the instrument to require 
the data. The theoretical foundations needed to be adapted in arranging a list of the questions in which all of them were based on the theory or quoted [15],[24]-[26]. The questionnaire includes open and close-ended questions to gain more proper answers.

\section{Results and Discussion}

\subsection{The students' constraints}

The following table below presents the constraints faced by the non-English students dealing with the questions of reading comprehension ITP TOEFL test.

Table 2. The constraints on reading comprehension TOEFL.

\begin{tabular}{clcccc}
\hline No & \multicolumn{1}{c}{ Statements } & $\begin{array}{c}\text { Strongly } \\
\text { Disagree }\end{array}$ & Disagree & $\begin{array}{c}\text { Strongly } \\
\text { Agree }\end{array}$ & Agree \\
\hline 1 & $\begin{array}{l}\text { I have limitated vocabulary, then it is } \\
\text { hard to understand the text. }\end{array}$ & $11,1 \%$ & $5,6 \%$ & $5,6 \%$ & $77,8 \%$ \\
$\quad \begin{array}{l}\text { I know the meaning whether it is } \\
\text { mentioned or unmentioned in the }\end{array}$ & - & $27,8 \%$ & $5,6 \%$ & $66,7 \%$ \\
$\begin{array}{l}\text { passage. } \\
3\end{array}$ & $\begin{array}{l}\text { I cannot locate the main idea } \\
\text { It is difficult to locate reference which }\end{array}$ & $5,6 \%$ & $55,6 \%$ & - & $38,9 \%$ \\
$\quad \begin{array}{l}\text { is asked in the passage } \\
\text { It is hard to find out the meanings } \\
\text { from structural clues }\end{array}$ & $5,6 \%$ & $50 \%$ & - & $44,4 \%$ \\
6 & $\begin{array}{l}\text { I do not know how to look for some } \\
\text { particular information. }\end{array}$ & - & $11,1 \%$ & $5,6 \%$ & $83,3 \%$ \\
$\quad \begin{array}{l}\text { I have no ability to determine the } \\
\text { text's tone, aim, or couse. }\end{array}$ & $5,5 \%$ & - & $72,2 \%$ & $22,2 \%$ \\
\hline
\end{tabular}

Table 2 covers all of the possible constraints of answering the questions on reading. The first is the non-English students got difficulty understanding the passage because of a lack of vocabulary which is proved by the $77,8 \%$ of all of the participants who chose to agree. Net, about $83,3 \%$ of students prefer to choose to agree with statement number 6 , it indicates that the students are complicated to comprehend the specific information from the passage. Lastly, the students encounter the struggle to identify the tone, purpose, or course in the passage intended to $72,2 \%$ of students recognized the answer strongly agree. Furthermore, there are three most constraints faced by the non-English student to answer reading comprehension questions on TOEFL.

As stated by Nuttal, he recognized five types of the difficulties found by the students; feel struggling in reading comprehension; determining the idea, locating reference, understanding vocabulary, making an inference, and determining the detailed information [15]. Based on the data above, the non-English students got difficulty in understanding the passage because of lack of vocabulary as stated;

"I found it difficult when the theme of passage opposite with my background education because there are many vocabularies that I did not know" (Respondent 17)

By the same token, vocabulary is one of the foremost components which judged as the reason why the students hard to understand the passage. The inability to identify some 
unfamiliar words in the text at high density can become an obstacle in the TOEFL [27]. Likewise, the students have no ability to search for specific information in the passage.

"In general, I frequently face or find a difficult thing like the passage of reading comprehension that has hard content to be understood. Sometimes, I cannot understand a passage that contains specific information that I ever heard before and contains the difficult words". (Respondent 3).

This result is in line with the study by Antoni who has investigated that the learners commonly gain any obstacles in taking the information because they cannot reach the ideas stated in the passage [28]. The problems may occur for any factors; lack of vocabulary and could not manage the time. Similarly, Oktarina revealed four difficulties oftentimes confronted by the learners; the matter of main idea, detailed information, unmentioned statement, and limited vocabulary [3]. Lastly, this difficult item that claims as one of the most problems chosen by the respondents is the struggle to recognizing the tone, purpose, or course in the passage.

"I think the difficult thing it is about referred to "object and back on paragraph". (Respondent 1)

"Closest meaning on the passage for me is kind of hard (unpredictable) question if I personally have lack of vocabs". (Respondent 6)

In the same way, it is also clarified by Sunayana and Shadi that some of the students are complicated to manage their reading speed ability in which they still hard to read properly, then it brings up the obstacle to determining the topic of the passage [29]. Therefore, those are the most difficulties that come up with the non-English students answering the reading comprehension TOEFL test.

\subsection{The students' strategies}

The following table shows the strategies applied by the non-English students in answering reading comprehension ITP TOEFL test which gathered from the online questionnaire.

Table 3. The strategies encountered by students.

\begin{tabular}{|c|c|c|c|c|c|}
\hline No & Statements & Never & Sometimes & Often & Always \\
\hline 1 & I observe any keywords to find main idea & - & $33,3 \%$ & $27,8 \%$ & $38,9 \%$ \\
\hline 2 & I can skim to define the main idea & - & $44,4 \%$ & $38,9 \%$ & $16,7 \%$ \\
\hline 3 & $\begin{array}{l}\text { Keep focus on the purpose of what I search } \\
\text { of when reading the passage }\end{array}$ & - & $16,7 \%$ & $55,6 \%$ & $27,8 \%$ \\
\hline 4 & $\begin{array}{l}\text { I link my knowledge with the text when I } \\
\text { read it }\end{array}$ & $5,6 \%$ & $33,3 \%$ & $50 \%$ & $11,1 \%$ \\
\hline 5 & $\begin{array}{l}\text { I use prediction skill when I read the } \\
\text { passage }\end{array}$ & $5,6 \%$ & $44,4 \%$ & $22,2 \%$ & $27,8 \%$ \\
\hline 6 & Implementing skimming method & $5,6 \%$ & $27,8 \%$ & $44,4 \%$ & $22,2 \%$ \\
\hline 7 & $\begin{array}{l}\text { Guessing a meaning through activating my } \\
\text { background knowledge }\end{array}$ & $5,6 \%$ & $38,9 \%$ & $44,4 \%$ & $11,1 \%$ \\
\hline 8 & I make a literal translation & - & $55,6 \%$ & $27,8 \%$ & $16,7 \%$ \\
\hline 9 & I read the passage in detail & $5,6 \%$ & $33,3 \%$ & $33,3 \%$ & $27,8 \%$ \\
\hline 10 & $\begin{array}{l}\text { I pay attention of the clue when I do not } \\
\text { understand the text }\end{array}$ & $5,6 \%$ & $11,1 \%$ & $50 \%$ & $33,3 \%$ \\
\hline 11 & $\begin{array}{l}\text { I just keep focus to read even I found many } \\
\text { unfamiliar words }\end{array}$ & - & $38,9 \%$ & $50 \%$ & $11,1 \%$ \\
\hline 12 & I repeatedly read the text if I could not & - & $16,7 \%$ & $55,6 \%$ & $27,8 \%$ \\
\hline
\end{tabular}


Table 3 indicates the strategies applied by the students dealing with the questions of the reading section in the TOEFL test. There are eight strategies mostly encountered by the students. Firstly, statement number 3 shows $55,6 \%$ of 18 students implemented this strategy in answering the question. Then, about half of the participants often used their background knowledge when reading a passage. Regarding to the number 6 , about $44,4 \%$ of students apply the strategy of still focus on the foremost information through skimming. It also appears in the next statement with a similar percentage of the previous statement in which the students guess the meaning by linking their prior knowledge with what they read. Next, 9 of 18 students utilized to recognize any clues in the passage to find the meaning of the unfamiliar words. To know them, the students often utilized the guessing from the suffixes and prefixed words, and linguistic knowledge. It is proved by the $50 \%$ of the participants in statements number 11 . Lastly, about 55,6\% of the total participants take the number 12 as the strategies in answering reading TOEFL in which they are still focus on read the text even they face many unfamiliar words, and repeat to read the passage to increase their understanding.

When the students revealed any constraints to comprehend the passage, it is appropriate to investigate some strategies they applied to accomplish those struggles.

"I have to scanning the main idea of the topic". (Respondent 1).

"Trying to understand the passage by understanding the passage contextually". (Respondent 14).

"Sometimes, I don't read the whole paragraph. I only read where the keyword is, and focusing on it". (Respondent 16).

"I try to guess the meaning even that is not easy". (Respondent 17).

Lestari and Syaifullah also found in their study regarding the strategy frequently applied by non-English students [30]. Firstly, predicting strategy. This strategy helped the informant to make connections between his prior knowledge and the passage. By ensuring that he had sufficient background knowledge before beginning to read the text, it could also help him successfully making predictions about the text. Skimming was used by the participants to the process of understanding the passage to get an overall impression of the content. Meanwhile, scanning is a reading strategy used when they want to find specific information quickly. Lastly, re-reading. In this case, the students reread the text slowly and paid attention to the words and meaning more carefully.

Similarly, the rest of the strategies usually applied by the non-English students in this study are; guessing based on their background understanding, re-read the text even found any unaccustomed words, and using the clues.

"When I face a difficult passage in reading comprehension, I usually try to read it repeatedly till I can get the man topic of the passage. In addition, when I get a hard word to be translated, I usually read the previous sentence for understanding difficult word or sentence". (Respondent 4)

According to Samad et al., he also found the strategies applied by the students facing reading comprehension TOEFL test, namely; skimming the passage, focus to keep in mind a purpose and still concentrate on the passage, guessing the meaning, translating the passage, understanding the question first, and read through even the passage is really hard to understand [20]. As agreed by Antoni, he stated that the students generally implemented any ways on answering the questions, then they would be passed the test well [28]. 


\section{Conclusion}

This study explored how non-English students deal with the constraints faced in reading comprehension tests, and investigated any strategies to resolve those struggles. Therefore, most of the adversities found based on the data collected are difficult to understand the passage because of the lack of vocabulary, complicated to comprehend the specific information from the passage, and the struggle to identify the tone, purpose, and course. Consequently, the strategies mostly implemented by them to solve those difficulties are; keep in mind of a purpose and concentrate of what they propose, use the prior knowledge, focus on what they read, use background knowledge when reading the passage, focus on the foremost element by skimming method, guessing the meaning, using context clues, and guessing.

Acknowledgments. The researcher expresses her highest and biggest gratitude to God Allah SWT who has been giving her the mercy, power, healthy, courage, and the blessing for arranging and publishing this journal. Salam and Shalawat are always sent to the lord of the great prophet Muhammad SAW. Thank you to Prof. Dr. Didi Sukyadi, M.A and Pupung Purnawarman, M.S.Ed., Ph.D as the lecturers who always guide, help and motivate the writer to finish and publish this research. Finally, the researcher would like to deliver her appreciation for the people who unstop to always spend their time to pray, guide, and help her until the researcher finished this journal. 


\section{References}

[1] Grabe, W. Reading in a Second Language: Moving from Theory to Practice. United Stated of America (USA): Cambridge University Press. 2005.

[2] Collins, H. Collin English Dictionary. Complete and Unabridged 10th edition. Amerika: Willian Collins Sons \& Co. Ltd. 2014.

[3] Oktarina, R. Difficult Skills in Reading Section of TOEFL Faced by Sixth Semester English Students. 2018.

[4] Tomi, M. Reading comprehension in the TOEFL PBT: Which sub-skills deserve more intensive training. Proceedings of the International Conference on the Teaching and Learning of Languages (ICTLL). 2017.

[5] Phakiti, A. Modelling Cognitive and Metacognitive Strategies and Their Relationship to EFL Reading Test Performance. Melbourne Paper in Language Testing. 2006. Vol. 11, no. 1.

[6] Warfield, W., Laribee, R., \& Geyer, R.W. "Examining Results and Establishing Benchmark Data from the TOEFL ITP test". American Academic \& Scholarly Research Jornal. 2013.5 (3), 191-198.

[7] Kurasi, Syamsuriana. The Correlation Between the Students' Attitude and English Proficiency of the Second Year Students of SMK Negeri 1 Enrekang. UIN Alauddin Makassar. 2012.

[8] Abboud, Z.A.R., Hussein, N.J. The difficulties faced by advanced Iraqi foreign learners in passing ITP TOEFL test. Journal of Basrah Researchers (Humanities Series). 2011. 36(4):110-138.

[9] Philips, D. Longman Preparation Course for the TOEFL Test. London: Longman. 2003.

[10] Celce-Murcia, M. Teaching English as a Second and Foreign Language (Third Edition). Boston: Heinle and Heinle Thomson Learning Inc. 2001.

[11] Fjeldstad, M. C. The Thoughtful Reader: A Whole Language Approach to College Reading. Now York: Harcourt Brace \& Company. 1994.

[12] Fitriani, S. S. Improving Reading Comprehension of Acehnese EFL Students. Unpublished Doctoral Dissertation. University of New England: Armidale. 2015.

[13] Healy, C. Reading: What the Experts say. Parent Educational Advocacy Training Center. 2002.

[14] Ali, H. "The Use of Silent Reading in Improving Students' Reading Comprehension and their Achievement in TOEFL Score at Private English Course". International Journal of Basic and Applied Science. 2014. 1(1), 47-52.

[15] Nuttal, C. Teaching Reading Skill in A Foreign Language. London: Richard Clay Ltd, Bungay, Suffolk. 1982.

[16] Chawwang, N. An Investigation of English Reading Problems of Thai 12th Grade Students in Nakhon Ratchasima Educational Region 1, 2, 3, and 7. (Unpublished Doctoral Dissertation). Srinahkarinwirot University Bangkok. 2008.

[17] Mahmud, M. The EFL Students Problems in Answering the Test of English as a Foreign Language (TOEFL: A Study in Indonesia Context). Theory and Practice in Language Studies. 2014. 4(19): 2581-2587.

[18] Carrell, P. L and W. Grabe. Reading. An Introduction to Applied Linguistics. Ed. N. Schmitt. London: Arnold. 2002. 233-250.

[19] Skehan, P. Task-Based Instruction. Annual Review of Applied Linguistics. 1998. 18, 268-286.

[20] Samad, I. A., Jannah, M., \& Fitriani, S. S. Efl Students'strategies Dealing With Common Difficulties In Toefl Reading Comprehension Section. International Journal of Language Education. (2017). 1(1). 29-36.

[21] Kirk, J., Miller, M. L., \& Miller, M. L. Reliability and validity in qualitative research (Vol. 1). Sage. 1986.

[22] Adler, E., \& Clark, R. How It's Done: An Introduction to Social Research. Mason: Cengage Learning. 2008.

[23] Carson, J. E., Carrell, P. L., Silberstein, S., Kroll, B., \& Kuehn, P. A. Reading writing relationships in first and second language. TESOL Quarterly. 1990. 24, 245-266.

[24] Karbalaei, A. A comparison of the metacognitive reading strategies used by EFL and ESL readers. The Reading Matrix. 2010. 10(2).

[25] Shang, H. F. Reading Strategy Use, Self-Efficacy and EFL Reading Comprehension. The Asian EFL Journal Quarterly. 2010. 12(2), 18-42. 
[26] Wang, C., \& Li, Y. An Empirical Study of Reading Self-efficacy and the Use of Reading Strategies in the Chinese EFL Context. The Asian EFL Journal Quarterly. 2010. 12(2), 144-162.

[27] Chall, Joanne, S. "Two Vocabularies for Reading: Recognition and Meaning”. M.G. Mc.Keown and M.E Curtis (eds). The Nature of Vocabulary Acquisition (Hillside, NJ. Lawrence Erlbaum). 1987. 717.

[28] Antoni, R. "An Analysis on 6th Semester Students' TOEFL Experience at English Department of Teachers Training and Education Faculty of Pasir Pengaraian University. Journal Imliah Edu Research. 2014. 391. 9-16.

[29] Manoj, S., and Hijazi, S. "Test Preparation Strategies for the TOEFL Can Be Diverse and Effective." International Journal of ELT, Linguistics and Comparative Literature 6.1. 2018. 5-9.

[30] Lestari, Sri \& Syaifullah. "A Narrative Research: A Student's Strategies in Reading Comprehension on TOEFL at the Eight Semester of English Education Department of Lancang Kuning University". ELT-Lecture: Journal Pendidikan. 2017. Vol 4, No.2. 